\title{
Mastery Learning Strategy and Learning Retention: Effects on Senior Secondary School Students' Achievement in Physical Geography in Ganye Educational Zone, Nigeria
}

\author{
Jacob Filgona ${ }^{1, *}$, Joel Filgona ${ }^{2}$ and Linus K. Sababa ${ }^{3}$ \\ 1 Government Day Secondary School Monduva, Mubi South LGA, Nigeria \\ 2 Department of Educational Foundation, Adamawa State University, Mubi, Nigeria; sadayaba@gmail.com \\ 3 Department of Biological Science, Adamawa State University, Mubi, Nigeria; sababalinus1234@gmail.com \\ * Correspondence: filgonajeff@gmail.com Tel: +2348100109939
}

\begin{abstract}
The need to alleviate the difficulties of abstraction and improve students' achievement in Physical Geography informed this research. This study investigated the Effects of Mastery Learning Strategy and Learning Retention on Senior Secondary School Students' Achievement in Physical Geography. The study adopted the quasi experimental non-equivalent pre-test, post-test control group design. The Multi-stage sampling technique at four levels was used to select four co-educational secondary schools in Ganye Educational Zone in Nigeria. The sample for the study was 218 Senior Secondary School two (SS II) students offering Geography from four intact classes in the four selected secondary schools. The instrument used for data collection was "Physical Geography Achievement and Retention Test" (PGART). The reliability of the instrument was established using Kendall tau $\underline{b}$ statistic. This gave a reliability index of 0.74 . Data collected were analyzed using Mann-Whitney U and t-Test. The results showed that Mastery Learning Strategy has the potentials to improve students' learning outcomes, retention and achievement in all spheres of cognitive domain in Physical Geography better than the Conventional Method. Hence the need to incorporate this teaching strategy during instruction so that learners would be guided to learn meaningfully and be assisted to retain content learnt in Geography.
\end{abstract}

Keywords: mastery learning strategy; learning retention; achievement; physical geography; conventional method

\section{Introduction}

The knowledge of geography is not only important and useful to the learners, but to everyone who seeks to cope with the ever-changing trends of our environment. The earth being the theatre where virtually all human activities take place is the focus of geographical study. Therefore, it is plausible that man knows about the nature and phenomenon on earth and the consequences of the interactions between man and his physical environment. In Nigeria, geography is an important school subject as is manifested in the general objectives of teaching and learning of geography. The former curriculum was limited to factual, examination-oriented approach, but today, there is greater emphasis on the educational and experiential implications for the students.

In the past, teachers are much more concerned merely with turning out students who are loaded with theoretical facts and terminologies in Geography. Today, the curriculum had changed. It has become a matter of investigation, inquiry and experiential. Emphasis is now placed on the relevance of Geography to life. This is evidenced by objectives that now guide the formulation of Geography curriculum which include: - To provide a vehicle for the child's development. To help the child 
acquire the art of using knowledge or to learn something about his cultural heritage; to provide necessary background to citizenship and intimate students into a particular mode of thought. Furthermore, the teaching of geography should offer a unique means of furthering inquiry and high intellectual growth in students. It should help man to live, place himself in the world and to learn his true position and what his duties are. It should help the students to understand and develop positive attitudes to race, culture and other people's environments and places. From these objectives, geography is not only taught for the learners' acquisition of knowledge but also to develop certain values and skills such as respect for others' values, sound judgement, keen observation, accurate measurement and reflective thinking among others. The acquisition of these values and skills will help the learners to cope with the challenges in their daily lives.

In Nigeria secondary schools, geography instruction is broadly categorized into three; physical, human and regional geography. This study centred on physical geography; because students often have showed some difficulties in it. Also, reports of students' performance in this aspect of geography in Senior Secondary School Certificate Examinations conducted by both West African Examinations Council (WAEC) and National Examination Council (NECO) have not been encouraging [1].

The teaching of Geography as science or social science subject in senior secondary schools in Ganye Educational Zone is not without its problems. These problems, ranging from Government, teachers and students-related problems does not differ with that bedeviling the entire education system in Nigeria. Poor academic achievement of students in all science subjects and Geography in particular has been a source of concern to many researchers. Students' academic achievement is being used as one of the predictors of overall quality of education system. It is true that where there is inadequate or poor funding of schools, there would be inadequate instructional materials, poor infrastructural facilities, poor teaching learning environment, and etcetera. As such, students in this locality see Geography as a collection of mere ideas presented as facts. They find geographical concepts confusing and unfamiliar. Students therefore, learn geographical concepts in abstract form and are subjected to too much imagination of geographical features instead of learning through active involvement. In addition, reports have shown that undue emphasis on theoretical aspects of Geography to the detriment of scientific and experiential approach had made the subject very abstract and uninteresting. Subsequently, the subject no longer attracts young scholars due to this dull, uninspiring and stereotyped approach being adopted [2]. Filgona, Sababa and Filgona [3] and Suwopoleme et. al. [1] identified dearth of instructional materials in Nigerian secondary schools as one of the problems affecting the teaching and learning of Geography. With this, teachers would be left with no option than to be glued strictly, to the chalk and talk approach of teaching and learning. This may in turn impact negatively on the achievement of students.

Going by interaction the researcher had with students in the course of this study, students in secondary schools of Ganye Educational Zone complain of poor choice of instructional strategies used by Geography teachers while teaching. These methods, they said, was not capable of arousing and sustaining their interest in the subject. The students during classes also observed some terminologies in Physical Geography such as the Localith, Batholith, Dyke, Sill, Stack and Stump 
among others, as appearing too abstract to them. And just when they are trying to assimilate the previous topics taught, the teachers come up with new ones. This has made their learning of Geography difficult thus affecting their performance in both internal and external examinations. If these observations are true, there seems to be no glimmer of hope for the future of Geography in this region.

Underpinning the observations made by students in the study area is the fact that choice of lecture method by Geography teachers may be due to poor motivation, dearth of instructional materials and haste to cover the syllabus expediently, not necessarily paying attention whether the students understood or not. Studies on underachievement of students in secondary school subjects reported inefficient teaching methods by school teachers as a major factor for the underachievement of students [4-5]. However, one may want to dismiss these claims made by the students with just a wave of a hand. This is so because, it is a common knowledge that students claim "the success" when they have a good grade; and quickly blame the teachers for their bad grades. But on a closer look, since the teacher happens to be the cynosure of all eyes in Nigeria's educational system and on whom the implementation or otherwise of the curriculum hinges; his role in ensuring better achievement of students cannot be overemphasized. More to this, studies have shown a decline in students' performance in sciences (Geography inclusive) and partly, this has been attributed to the fact that strategies used in our classrooms are not very effective [6-7].To this end, one may say that the quality of education provided to students is intricately linked to the strategies teachers adopt in passing on knowledge to students in the classrooms. Although, the poor performance of students could be attributed to the low quality of teachers in some cases, a positive correlation between teachers' strategy and students' academic achievement in Geography has been observed [8].

The foregoing underscores the importance of teacher pedagogical prowess in achieving quality education and as correlate of students' academic achievement. Persistent use of traditional teaching methods such as the lecture in Geography classrooms has been advanced as the underlying factor for students' poor performance in the subject [6]. However, this is not to say that the use of lecture method in teaching and learning over the years has not yielded any positive results. Clar and Wareham [9] observed that Geography teachers have traditionally used lecture as teaching method than many other subjects and its usage has expanded further over the last few years. If the method a teacher adopts in teaching; and poor retention of the concepts in Geography by students are some of the major reasons for the poor performance of students in Geography, then the questions are; 'how can we break this circle of failure'? What can we do as teachers to remedy the problem of students in Physical Geography in the study area? Is there a teaching strategy that could help students to overcome learning problems in Physical Geography?

Different methods and techniques for imparting instructions in a formal classroom setting have been in flux overtime; old ones being replaced by newer and effective ones. Educationists now believe that all can learn well under a set of certain condition. This change in thought has revolutionized the whole concept and processes of teaching in classrooms. It provides a platform where teachers and students get involved in an all inclusion teaching and learning process; a phenomenon that allow students to feel and put into practice what they are being taught thus reducing the abstraction 
associated with using the traditional teaching methods. Mastery Learning Strategy is one of such techniques that could provide remedial to students difficulties in Physical Geography.

Mastery Learning Strategy (MLS) is an instructional strategy where students are allowed unlimited opportunities to demonstrate mastery of content taught. It is an instructional strategy in which learners are provided with the opportunity to master a particular unit of lesson before proceeding to the next. Most modern applications of mastery learning stem from the writings of Benjamin S. Bloom; even though the idea of the instructional strategy dated back to earlier years [10]. Bloom [11] hypothesized that a classroom with a mastery learning focus as opposed to the traditional form of instruction (lecture method) would reduce the achievement gaps between learners of varying degrees of academic abilities. Bloom's theory of school learning asserts that virtually all students can learn what they are taught if given the appropriate and prior conditions.

Mastery learning instructional strategy divides subject matter into units that have predetermined objectives or unit expectations. Students, alone or in groups, work through each unit in an organized manner. The teacher assesses and grades the students after each unit to determine who has mastered the content and who needs more help. Students must demonstrate mastery on unit tests, typically $80 \%$, before moving on to new material [12-13]. Students who have mastered the material are given enrichment opportunities which could be in the form of projects or problem solving tasks. Students who do not achieve mastery receive remediation through tutoring, peer monitoring, small group discussions, or additional assignment. Additional time for learning is prescribed for those requiring remediation. In this manner, students continue the cycle of studying and testing until mastery is achieved, after which they can proceed to more advanced learning tasks. The assumption here is that, if students are given opportunity to learn and time allowed for learning coupled with quality of instruction that will match their need and situation, at least $80 \%$ or higher, could achieve mastery in learning. Based on this, Bloom developed a mastery learning model called Learning for Mastery (LFM). However, the question still begging for answers in the study area is 'would the use of Mastery Learning Strategy enhance students' understanding of concepts and improve achievement in Physical Geography?'

Abakpa and Iji [14] opine that mastery learning strategy can provide quality instruction, immediate feedback and remedial lessons for the attainment of lesson objectives. Studies by [14-15] all affirm that mastery learning strategy enhances students' academic achievement and retention in integrated science and mathematics than the conventional method. More recent works by Hussain and Suleman [16], Lamidi, Oyelekan and Olorundare [17], Udo and Udofia [18] all affirms the superiority of mastery learning strategy over the conventional lecture method. The findings from these works revealed that the students taught using mastery learning approaches performed better than their counterparts taught through the conventional method. Therefore, since mastery learning strategy could improve the achievement of students in the studies highlighted, there is the possibility that it could alleviate students' difficulties in Physical Geography observed in the study area. 
Studies have highlighted the veracity of student-centred approaches in promoting better understanding and material retention by students [6, 19]. Learning retention in respect to this study is the ability of the students to acquire and comprehend the knowledge of physical Geography. The retention is exhibited in the successful performance in the tests designed to measure the learner's achievement. Mastery Learning Strategy takes place in an increasing order of difficulty. According to Bloom taxonomy of behavioural objectives, learners graduate from learning concepts in lower order (knowledge, comprehension and application) to higher order (analyses, syntheses and evaluation) cognitive domain. A poor understanding of concepts at the lower order domain of learning could deter a learner from moving to the higher order domain. This is where mastery learning is crucial; by ensuring that all learners have a better understanding of the concepts taught before proceeding to the next level. Studies have shown that students taught using students-centred instructional strategies other than lecture method achieve greater material retention [3-20]. Furtherance to this, Hussain and Suleman [16] conducted a study using the Bloom's Mastery Learning approach to teach English Language at secondary school level in Pakistan. The findings showed that Bloom's Mastery Learning approach was more effective on student's retention compared to traditional learning approach.

While much has been done on the effects of mastery learning strategy on students' achievement in different subjects and in various localities; there is paucity of data on the extent it could impact on students' achievement with specific emphasis on Physical Geography. To this end, this study was carried out to provide empirical evidence on the Effects of Mastery Learning Strategy in conjunction with Learning Retention on Senior Secondary School Students' Achievement in Physical Geography.

\subsection{Purpose of the Study}

This study investigates the effects of Mastery Learning Strategy and Learning Retention on Senior Secondary School Students' Achievement in Physical Geography in Ganye Educational Zone, Nigeria. The specific objectives of the study were enumerated as follows:

(i) to determine the achievement of students taught Physical Geography using Mastery Learning Strategy and Conventional Method;

(ii) to examine the Learning Retention of students taught Physical Geography using Mastery Learning Strategy and Conventional Method;

(iii) to evaluate the achievement of students in the Lower Order (knowledge, comprehension and application) and the Higher Order (analysis and synthesis) Cognitive Domain taught Physical Geography using Mastery Learning Strategy; and

(iv) to evaluate the achievement of students at different levels of Cognitive Domain i.e., knowledge, comprehension, application, analysis and synthesis taught Physical Geography using Mastery Learning Strategy and Conventional Method. 


\subsection{Research Hypotheses}

The following hypotheses were formulated and tested at 0.05 level of significance:

Ho1: There is no significant difference in the achievement of students taught Physical Geography using Mastery Learning Strategy and Conventional Method.

Hoz: There is no significant difference in the Learning Retention of students taught Physical Geography using Mastery Learning Strategy and Conventional Method.

Hоз: There is no significant difference in the achievement of students in the Lower Order (knowledge, comprehension and application) and the Higher Order (analysis and synthesis) Cognitive Domain taught Physical Geography using Mastery Learning Strategy.

Ho4: There is no significant difference in the achievement of students at different levels of Cognitive Domain i.e., knowledge, comprehension, application, analysis and synthesis taught Physical Geography using Mastery Learning Strategy and Conventional Method.

\section{Materials and Methods}

This study employed the quasi-experimental design. The non-equivalent, pre-test and post-test control group design was adopted to test the hypotheses. The design is thus represented as follows:

$\mathrm{O}_{1} \quad \mathrm{X}_{1} \mathrm{O}_{2}$

$\mathrm{O}_{3} \quad \mathrm{X}_{2} \quad \mathrm{O}_{4}$

where:

$\mathrm{O}_{1}$ and $\mathrm{O}_{3}$ are Pre-test Scores for the two groups

$\mathrm{O}_{2}$ and $\mathrm{O}_{4}$ are Post Test Scores for the two groups

$\mathrm{X}_{1}=$ Experimental treatment using Mastery Learning Strategy (MLS)

$\mathrm{X}_{2}=$ Control treatment using Conventional Method

\subsection{Sample and Sampling Technique}

The Multi-stage sampling technique at four levels was used for the study. At the first level, simple random sampling technique involving the use of balloting without replacement was used in selecting two out of four Local Government Areas in Ganye Educational Zone. The two LGAs that emerged after selection were Toungo and Ganye. At the second level, two senior secondary schools from each of the two selected LGAs were sampled using stratified random sampling technique. In 
each of the Local Government Areas, one of the selected schools was assigned Experimental treatment and the other Control treatment groups.

At the fourth level of the sampling procedure, one intact class from the four senior secondary schools used in the study was selected using simple random sampling technique involving the use of balloting without replacement. Therefore, the sample size for the study consisted of 218 Senior Secondary School two (SS II) students offering Geography in four intact classes from four government-owned secondary schools in Ganye Educational Zone. Two of the intact classes consisting of 113 (Class A: 58, Class B: 55) students were later clustered and assigned the Experimental Group. They were taught concepts in Physical Geography using Mastery Learning Strategy. The remaining two intact classes consisted of 105 (Class C: 51, Class D: 54) students, clustered and assigned the Control group and taught using Conventional Method. The four schools used for the study were co-educational schools in Ganye Educational Zone.

\subsection{Research Instrument}

A 40-item Physical Geography Achievement and Retention Test (PGART) was used. It was constructed by the researcher and patterned in line with WAEC questions in Physical Geography. The Blooms taxonomy of behavioural objectives was used as a guide to structuring the items in the instrument. This was done in order to test the students' mastery of concepts in Physical Geography at all cognitive levels. The PGART consisted of two sections. Section A comprised of 35 multiple choice items carrying 35 marks while Section B, carried 65 marks and consisted of 5 essay items from which any 3 was answered. The duration set for students to answer these questions was $1 \mathrm{hr}$. 30mins.

Items in the instrument were drawn from topics in Physical Geography as specified in the Nigeria's Geography Curriculum for Senior Secondary School two (SS II) students. The topics are: earthquake, vulcanicity, faulting and folding, weathering and mass movement. Item specification for the PGART instrument measuring five cognitive domains in the Blooms taxonomy of behavioural objectives is represented on Table 1.

Table 1: Item Specification for the Physical Geography Achievement and Retention Test (PGART)

\begin{tabular}{|c|c|c|c|c|c|c|}
\hline Topic & $\begin{array}{c}\text { Knowledge } \\
(25 \%)\end{array}$ & $\begin{array}{c}\text { Cognitive } \\
\text { Comprehension } \\
(25 \%)\end{array}$ & $\begin{array}{l}\text { Objectives } \\
\text { Application } \\
(25 \%)\end{array}$ & $\begin{array}{c}\text { Analyses } \\
(12.5 \%)\end{array}$ & $\begin{array}{c}\text { Syntheses } \\
(12.5 \%)\end{array}$ & $\begin{array}{r}\text { Total } \\
(100)\end{array}$ \\
\hline Earthquake & 2 & 2 & 2 & 1 & 1 & 8 \\
\hline Vulcanicity & 2 & 2 & 2 & 1 & 1 & 8 \\
\hline \multicolumn{7}{|l|}{ Folding } \\
\hline Weathering & 2 & 2 & 2 & 1 & 1 & 8 \\
\hline Mass & 2 & 2 & 2 & 1 & 1 & 8 \\
\hline \multicolumn{7}{|l|}{ Movement } \\
\hline Total & 10 & 10 & 10 & 5 & 5 & 40 \\
\hline
\end{tabular}

Adapted from Filgona, [6]. 
Table 1 show that 25\% of the 40 items would test knowledge (i.e. 2 items), 25\% would test comprehension (i. e. 2 items), 25\% would test application ( 2 items), 12.5\% would test analyses (1 item) and $12.5 \%$ would test syntheses (1 item). The number of week(s) each topic lasted in the Post Primary Schools Management Board (PPSMB), Yola, common scheme of work for secondary schools Geography, formed the basis of weighting contents. The weighting for the cognitive objective was based on proportion of the lower and higher order behavioural objectives in the units of the study. Lower order cognitive objectives include levels of intellectual function objectives such as knowledge, comprehension and application while higher order cognitive objectives include analyses and syntheses. Each unit has 2 questions of lower order or $75 \%(25 \%+25 \%+25 \%=75 \%)$ of the total percentage and 1 question of higher order or $25 \%(12.5 \%+12.5 \%=25 \%)$ of the total percentage. Therefore, the sum total of lower order questions is $30(10+10+10)$ while higher order questions are $10(5+5)$. The sum total $=30+10=40$.

\subsection{Validity of the Instrument}

The PGART instrument was validated by three professional secondary school Geography teachers and two experts in Geography Education in the Department of Educational Foundation, Adamawa State University, Mubi. The validators looked at the suitability of the items to ascertain whether it was structured to measure the chosen topics. The validators also guided the researcher on mark allocation, duration of the study, marking scheme, lesson plans and other relevant areas. The criticisms and vetting by these experts helped in modifying and replacing some items. All criticisms and corrections proffered by the validators guided the production of the final draft of the instrument.

\subsection{Reliability of the Instrument}

The instrument was pilot tested using 60 SS II students offering Geography from two public senior secondary schools in Mayo Belwa Local Government Area. The scores of students obtained after pilot testing were correlated using Kendall tau $\underline{b}$ statistic. The statistic produced a reliability index of 0.74; which was considered satisfactory for the study.

\subsection{Procedure for Data Collection}

Data collection was categorized into four phases. The four phases involved were the preliminary, pre-treatment, treatment and the post-treatment stages.

Phase One: This was the preliminary stage. After due permission was sought from the authorities of the four selected schools. The researcher met with students to seek their consent and explained the aim of the study as well as their level of involvement in the study. Permission was sought to engage two geography teachers to serve as Research Assistants. Instructors were trained in the use of the manual (lesson plans). The training exercise was based on the purpose of the study, topics to be taught, strategies/method to be used, use of the lesson plans, administration of PGART as well as general conduct of the study. The research assistants were given lesson plans based on the 
Experimental treatment to be administered using Mastery Learning Strategy, and the Control using Conventional Method. Lesson plans on the selected topics from SS II Geography curriculum were prepared and used to teach students in the experimental and control groups. All participants were conferred, monitored, and assisted while the study was in progress.

Phase Two: This was the pre-treatment stage. In order to conduct the experiment successfully, pre-test was given to determine the existing knowledge of students before experimental process. The PGART instrument was administered as pre-test to the students in the two groups (experimental and control groups). The instruments contained 35 objectives items requiring students to circle the correct option from letter A-D; and 5 essay items from which students are required to write on any three comprehensively on the topics taught them in Physical Geography. This was done in the first week.

Phase Three: This was where the proper treatment administered to the experimental and control groups began. Students in both the experimental and control groups were taught the same topics in physical Geography but with different instructional strategies. The Experimental Groups were exposed to learning earthquake, vulcanicity, faulting and folding, weathering and mass movement in Physical Geography using Mastery Learning Strategy, while the control group was exposed to the same concepts using Conventional Method of teaching. The treatment lasted for four weeks.

Experimental Treatment: The experimental group, comprises 113 (Class A: 58, Class B: 55) students taught earthquake, vulcanicity, faulting and folding, weathering and mass movement in Physical Geography using the Mastery Learning Strategy by instructors in the mastery learning group. The Mastery Learning lesson plan was characterized by clear objectives, initial instruction, formative testing, remediation, and corrective and summative testing. Students were told objectives that were to be mastered and the level of mastery that was expected from them (usually $80 \%$ ). After initial instruction, a formative task was given to evaluate the achievement of mastery on the part of the students and instruction on the part of the teacher. If mastery was not achieved by students on the formative task, remediation and re-teaching of the students occurred. The remediation and re-teaching were different in approach from the original instruction. The students who had received remediation were again tested with a parallel task to the first formative task to see if mastery had been achieved. This remediation and re-teaching occurred while class was in session. After students had reached mastery, instruction proceeded to a new set of objectives. A summative test was given at the end of the study to measure students' achievement over all topics covered.

Control Treatment: In the control group, the 105 (Class C: 51, Class D: 54) students in the two intact classes were exposed to the same concepts in Physical Geography using the Conventional (Lecture) Method. This involved the teacher delivering lesson to the students using chalk and chalkboard. In this category, the teacher directs the teaching learning process and learners just listened and take notes. The focus here lies in knowledge transmission in an effort to cover the contents expediently without necessarily paying attention to whether learners understood or not. Teachers in this group were caution not to digress into any form of activity-based learning during lesson delivery, as they are to abide strictly to the guidelines provided in the lesson plans for Conventional Method. 
Phase Four: This was the post-treatment stage. After teaching the experimental and control groups using Mastery Learning Strategy and Conventional Method, the post test was administered. The post test (which was a reshuffled version of the pre-test) was administered on the Experimental and Control groups on the sixth week. The scripts of students in the two groups were collected for marking and were scored over 100, and the scores were used for further statistical analysis.

\subsection{Method of Data Analysis}

Prior to statistical analysis, the data (students test scores in the experimental and control groups) were subjected to normality test using the Shapiro Wilk test of normality to find out the statistical tool that could best be applied to test the hypotheses. The Shapiro Wilk test revealed that the data were not normally distributed for hypotheses one and two and normally distributed for hypotheses three and four. Hence, the non-parametric Mann Whitney U test was applied in testing hypotheses one and two while the paired samples t-test statistic was used to test hypothesis three and the independent $\mathrm{t}$-test was used for hypothesis four. Statistical Package for Social Sciences version 23 (SPSS Inc. Chicago, IL, USA) was used for analysis and probability level of $p<0.05$ was considered statistically significant.

\section{Results}

In order to determine the students' entry behaviour at the onset of the study; students' pre-test scores in the experimental and control groups were subjected to analysis using the Mann-Whitney $\mathrm{U}$ test. The result is presented in Table 2.

Table 2: Summary of Mann-Whitney U test of Pre-test Results of Students in the Mastery Learning Strategy and Conventional Method

\begin{tabular}{lccccc}
\hline Variable & N & $\begin{array}{c}\text { Mean } \\
\text { Rank }\end{array}$ & $\begin{array}{c}\text { Sum of } \\
\text { Ranks }\end{array}$ & U & $\begin{array}{c}\text { Asymp. Sig. } \\
\text { (2-tailed) }\end{array}$ \\
\hline $\begin{array}{l}\text { Mastery Learning } \\
\begin{array}{l}\text { Strategy } \\
\text { Conventional Method }\end{array}\end{array}$ & 113 & 105.17 & 11884.00 & & .292 \\
\hline
\end{tabular}

Not Significant, $\mathrm{p}>.05$.

The analysis in Table 2 reveals that there is no significant difference in the achievement of students in Physical Geography in the experimental and control groups before the treatment $(U=5443.00, p=$ 0.292). This indicates that the students had homogenous entry behaviour before the treatment.

\section{Hypotheses Testing}

Ho1: There is no significant difference in the achievement of students taught Physical Geography using Mastery Learning Strategy and Conventional Method. 
To test this hypothesis, the post test scores of students taught Physical Geography using Mastery Learning Strategy and Conventional Method was analyzed using Mann-Whitney U test statistic. The result shows that there is a significant difference in the achievement of students taught Physical Geography using Mastery Learning Strategy and Conventional Method $(U=3880.50, p=0.000)$ (Table 3).

Table 3: Summary of Mann-Whitney U test Results of Post Test Scores of Students in the Mastery Learning Strategy and Conventional Method

\begin{tabular}{lccccc}
\hline Variable & N & Mean & Sum of & U & Asymp. Sig. \\
& Rank & Ranks & & (2-tailed) \\
\hline $\begin{array}{l}\text { Mastery Learning } \\
\begin{array}{l}\text { Strategy } \\
\text { Conventional Method }\end{array}\end{array}$ & 113 & 127.66 & 14425.50 & & $.000^{*}$ \\
\hline
\end{tabular}

*Significant; $\mathrm{p}<.05$.

In other words, students post test scores of the experimental group taught by Mastery Learning Strategy exhibited significant differences when compared to those of the control group taught with Conventional Method. This finding indicates that the Mastery Learning approach is more effective in increasing students' achievement in Physical Geography.

Hoz: There is no significant difference in the Learning Retention of students taught Physical Geography using Mastery Learning Strategy and Conventional Method.

The learning retention of students in both knowledge and comprehension items in the two groups was evaluated. Results obtained shows a significant difference in the learning retention of students taught Physical Geography using Mastery Learning Strategy and Conventional Method $(\mathrm{U}=$ 2893.50, $\mathrm{p}=0.000)$. (Table 4).

Table 4: Summary of Mann-Whitney U test Results of Learning Retention of Students in the Mastery Learning Strategy and Conventional Method

\begin{tabular}{lccccc}
\hline Variable & N & $\begin{array}{c}\text { Mean } \\
\text { Rank }\end{array}$ & $\begin{array}{c}\text { Sum of } \\
\text { Ranks }\end{array}$ & U & $\begin{array}{c}\text { Asymp. Sig. } \\
\text { (2-tailed) }\end{array}$ \\
\hline $\begin{array}{l}\text { Mastery Learning } \\
\begin{array}{l}\text { Strategy } \\
\text { Conventional Method }\end{array}\end{array}$ & 113 & 136.39 & 15412.50 & & \\
\hline
\end{tabular}

*Significant; $\mathrm{p}<.05$.

This implies that students' retention scores in Physical Geography in the Mastery Learning Strategy group is significant compared to their counterparts in the control group. 
Hoз: The achievement of students in the Lower Order (knowledge, comprehension and application) and the Higher Order (analysis and synthesis) Cognitive Domain taught Physical Geography by Mastery Learning Strategy were compared using the paired samples t-test. The result reveals that the difference in the achievement of students in lower and higher order cognitive domain for Mastery Learning Strategy is not significant $(t=1.588, d f=225 ; p=0.114)$. (Tables 5).

Table 5: Summary of Paired t-Test Analysis of Post Scores of Students in the Lower Order and the Higher Order Cognitive Domain taught Physical Geography using Mastery Learning Strategy

\begin{tabular}{lcccccccc}
\hline Variable & & $\begin{array}{c}\text { Order of } \\
\text { Cognitive } \\
\text { Domain }\end{array}$ & N & Mean & SD & df & t & $\begin{array}{c}\text { Sig. } \\
\text { (2-tailed) }\end{array}$ \\
\hline $\begin{array}{l}\text { Mastery } \\
\text { Strategy }\end{array}$ & Learning & Lower & 113 & 50.05 & 16.39 & & & \\
$\begin{array}{l}\text { Mastery Learning } \\
\text { Strategy }\end{array}$ & Higher & 113 & 46.73 & 14.99 & & & \\
\hline
\end{tabular}

Not Significant; $\mathrm{p}>.05$.

Despite the fact that the students in the experimental group scored higher in the lower order cognitive domain $(M=50.05)$ compared to their mean score in the higher order cognitive domain ( $M$ = 46.73), the table depicts that the difference is statistically insignificant. This implies that the Mastery Learning Strategy enhance students' achievement across all levels of cognitive domain equitably.

Ho4: The achievement of students at different levels of cognitive domain i.e., knowledge, comprehension, application, analysis and synthesis taught Physical Geography by Mastery Learning Strategy and Conventional Method was analyzed using independent samples t-test. The results obtained reveals that there is a significant difference in the post test scores of students at different levels of cognitive domain taught Physical Geography using Mastery Learning Strategy and Conventional Method (Table 6). 
Table 6: Summary of $t$-Test Analysis of Post Test Scores of Students at different level of Cognitive Domain taught Physical Geography using Mastery Learning Strategy and Conventional Method

\begin{tabular}{|c|c|c|c|c|c|c|c|}
\hline $\begin{array}{l}\text { Cognitive } \\
\text { Domain }\end{array}$ & Teaching Method & $\mathbf{N}$ & Mean & SD & df & $\mathbf{t}$ & $\begin{array}{c}\text { Sig. } \\
\text { (2-tailed) }\end{array}$ \\
\hline \multirow[t]{4}{*}{ Knowledge } & Mastery Learning & 113 & 17.12 & 7.07 & & & \\
\hline & Strategy & & & & 216 & 8.350 & $.000^{*}$ \\
\hline & Conventional & 105 & 9.03 & 7.23 & & & \\
\hline & Method & & & & & & \\
\hline \multirow[t]{4}{*}{ Comprehension } & Mastery Learning & 113 & 17.07 & 7.58 & & & \\
\hline & Strategy & & & & 216 & 4.830 & $.000^{*}$ \\
\hline & Conventional & 105 & 11.79 & 8.56 & & & \\
\hline & Method & & & & & & \\
\hline \multirow[t]{5}{*}{ Application } & Mastery Learning & 113 & 18.58 & 7.20 & & & \\
\hline & Strategy & & & & & & \\
\hline & & & & & 216 & 7.797 & $.000^{*}$ \\
\hline & Conventional & 105 & 10.80 & 7.42 & & & \\
\hline & Method & & & & & & \\
\hline \multirow[t]{5}{*}{ Analyses } & Mastery Learning & 113 & 16.79 & 7.87 & & & \\
\hline & Strategy & & & & & & \\
\hline & & & & & 216 & 5.935 & $.000^{*}$ \\
\hline & Conventional & 105 & 10.67 & 7.32 & & & \\
\hline & Method & & & & & & \\
\hline \multirow[t]{4}{*}{ Syntheses } & Mastery Learning & 113 & 16.21 & 6.27 & & & \\
\hline & Strategy & & & & 016 & $4<c$ & $000 *$ \\
\hline & Conventional & 105 & 11.47 & 8.65 & & & \\
\hline & Method & & & & & & \\
\hline
\end{tabular}

*Significant; $\mathrm{p}<.05$.

Students taught Physical Geography through Mastery Learning Strategy performed better in all spheres of cognitive domain compared to their counterparts taught through the Conventional Method. This scenario could further be depicted graphically (Fig. 1). 


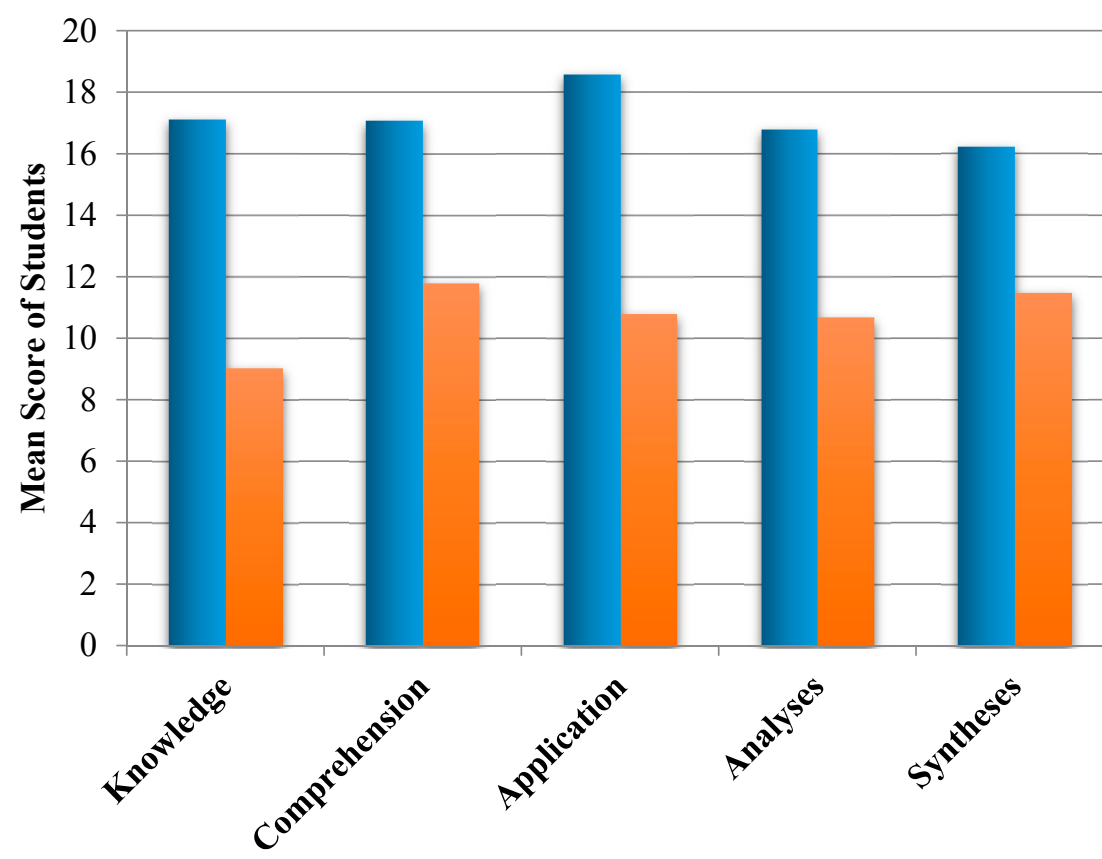

- Mastery Learning

Strategy

Conventional

Method

Cognitive Domain of Learning Objectives in PGART Instrument

Fig 1: A Bar Chart Showing Mean Score of Students at different Levels of Cognitive Domain taught Physical Geography using Mastery Learning Strategy and Conventional Method

\section{Discussion}

Mastery learning strategy offers re-teaching and re-testing procedures. It motivates students through verbal and written praises and also made sure that students master a unit before advancing to the next. In this study, the homogeneity of students' achievement in the experimental and control group prior to treatment was evaluated by subjecting their Pre-test score in Physical Geography to Mann-Whitney $U$ test. The analysis revealed that there is no significant difference in the achievement of students in Physical Geography in the experimental and control groups prior to treatment $(\mathrm{U}=5443.00, \mathrm{p}=0.292)$. This suggests that the two groups were quite homogenous; which implies that students used for the study have relatively equal background knowledge of Physical Geography.

Comparing students' achievement taught Physical Geography using Mastery Learning Strategy and Conventional Method by Mann-Whitney $U$ test indicated that students exposed to Physical Geography through mastery learning achieved remarkable results than their counterparts taught through the Conventional Method. This finding coincides with the works of [16], [21], [17], [18], [22] and [23] who found that Mastery Learning Strategy improved students' achievement better than the Conventional Teaching Method. Conversely, this finding is not in accordance with the work of Oluwatosin and Bello [12] who found out that student taught using Mind Mapping Approach achieved better results than their counterparts taught through Mastery Learning Approach and Conventional Method. It has been argued that conventional teaching method is content centred in which teachers remain more active, more cognitive and less effective [24] The method is concerned 
with the recall of factual knowledge and largely ignores higher levels of cognitive outcomes, the teacher seeks to transfer thoughts, and meanings to the learners leaving little room for student-initiated questions, independent thought or interaction between students; also, it is detrimental to students' learning process $[12,24,26,27]$. The use of this method might have influenced the achievement of students negatively in the Conventional Method group.

It was observed that students spent more time to achieve mastery in the first time instruction was given to them, but on subsequent instruction, they spent lesser time. This could be attributed to the fact that the first lesson was a prerequisite to the next lesson. Hence, time that was lost during the first lesson was recovered in the second lesson. The strategy facilitated a better understanding of the concept as students were not allowed to learn new lessons until the previous one was properly understood. This finding agrees with [28] who pointed out that teachers should have the knowledge of how students learn and how best to teach the concepts of a particular subject. Similarly, [29] noted that the teaching strategy that a teacher adopts is one factor that may affect students' achievement and therefore the use of an appropriate teaching method is critical to successful teaching and learning.

Mastery Learning is characterized by clear objectives, initial instruction, formative testing, remediation, and corrective and summative testing [16]. In this study, better Learning Retention of students in Physical Geography taught using Mastery Learning Strategy than those taught using the Conventional Lecture Method was observed. A study conducted by Davis and Sorrel [30] asserts that Mastery Learning had been proven to be positive and successful especially in the area of learning and retention of content. Similarly, the finding of this study buttresses the works of [16], [21] and [12] on the effect of Mastery Learning Strategy on students' achievement.

This study observes that Mastery Learning Strategy has the potentials of leveling up the achievements of learners across various cognitive domain of learning. Students taught Physical Geography using Mastery Learning Strategy achieved remarkable results in the lower and higher order cognitive domain tested. This finding is consistent with work of Hussain and Suleman [16] who reported that students who were taught through mastery learning strategy showed better performance in each level of cognitive domain. This is an indication that the learners had a better understanding of previous concepts in physical geography serving as a prerequisite to learning the future ones. This could have culminated to the remarkable success recorded by students in the experimental group at each level of cognitive domain that they were tested. In this study, peer tutoring was encouraged in and out of class time, where the students checked each other for mastery. They tutored one another and verified that everyone mastered the sub-topic and was ready for the test. Since Mastery Learning stresses need for formative assessment and feedback for each unit a variety of remediation materials were prepared. This could be advanced as the reason for the result obtained in this group.

Mastery Learning has been shown to promote high cognitive learning outcomes of students [31-34]. Similarly, this study also revealed that students who were exposed to Physical Geography through Mastery Learning were exceptionally better in each level of cognitive domain of learning compared 
to their counterparts in the control group. This finding corroborates other reports that found the Bloom's Mastery learning approach to be more effective, successful and useful in different level of cognitive domains i.e., knowledge, comprehension, application, analysis, synthesis and evaluation compared to traditional lecture method [16, 11].

The most important feature of Mastery Learning Strategy is that it accommodates the natural diversity in learning abilities among different groups of students. It provides flexibility platform that accommodates all students according to their respective levels of learning and understanding. This type of learning strategy does not only enhance students' achievement but also stimulate students to be more actively involved in the teaching learning process. This is unlike the conventional method where learners are passive during lesson delivery.

\section{Conclusion}

The Mastery Learning Strategy had been shown to be outstanding, effective and efficient in promoting the desired learning outcomes of students in Physical Geography. It gave students the opportunity to study a material unit after unit until they master it. Through differentiated and individualized instruction, progress monitoring, formative assessment, feedback, corrective procedures, and instructional alignment, students exposed to learning of concepts in Physical Geography using MLS retained the concepts better than their counterparts in the control group. Furthermore, the strategy enhanced students' achievement across all levels of cognitive domain; thus, establishing its efficacy in bridging the achievement gaps among learners of various abilities. Mastery Learning Strategy could therefore be used by Geography teachers in secondary schools to alleviate the difficulties students are faced with in Physical Geography.

\section{Recommendations}

The following are recommendations for the study:

This study provides empirical evidence on the effectiveness of MLS teaching strategy in enhancing academic achievement of students in Physical Geography. This implies that the use of MLS in the teaching of Physical Geography at secondary school level can address the poor achievement and low enrolment of students in the subject.

The Federal and State Ministries of Education and other educational bodies like Nigeria Educational Research and Development Council (NERDC) and the Science Teachers Association of Nigeria (STAN) should organize training/ workshops for Geography teachers. This could be done in order to update their knowledge on the use of the mastery learning instructional strategy to improve teaching and learning in Nigerian schools.

The curriculum developers should design curriculum based on mastery learning principles in teaching Physical Geography. Teachers on the other hand should be encouraged to adopt mastery learning approach of teaching in order to enhance the cognitive learning outcome of students in Geography. 
The teachers' educators will find the study useful in developing programmes aimed at producing teachers capable of meeting up with the ever evolving trends in the sphere of Education. In so doing, teachers would be equipped and be capable of structuring learning environment that can equalize their interaction with learners, enabling greater learner participation, satisfaction and further academic aspirations.

Acknowledgements: My heartfelt gratitude goes to the Principals, Research Assistants and the students in the various schools used for the study. I thank them for their immeasurable support given me in the course of this study.

Author Contributions: Jacob Filgona conceived and designed the experiments; Jacob Filgona performed the experiments; Jacob Filgona and Joel Filgona analyzed the data; Jacob Filgona Joel Filgona and Sababa L. K. contributed reagents, materials and analysis tools; Jacob Filgona wrote the paper.

Conflicts of Interest: The authors declare no conflict of interest.

\section{References}

1. Suwopoleme, S. E., Sababa, L. K., and Filgona, J. Effect of fieldtrip strategy on senior secondary school students achievement in Geography in Numan Educational Zone, Adamawa State, Nigeria. European Journal of Education Studies, 2016, 2(12): 138-154.

2. Sofowora, O. A., and Egbedokun, A. An empirical survey of technology application in teaching Geography in Nigerian secondary schools. Ethiopian Journal of Environmental Studies and Management, 2010, 3(10): 46-54.

3. Filgona, J., Sababa, L. K, and Filgona, J. Effect of hands-on learning strategies on senior secondary school students' academic achievement in topographical map studies in Ganye Educational Zone, Adamawa State, Nigeria. International Journal of Social Science and Humanities Research, 2016; 4(3): 276-287.

4. Pepple, T. F. Effects of cooperative learning and programmed instructional strategies on students' learning outcomes in chemistry. An unpublished Ph.D. Thesis, Delta State University, Nigeria, 2010.

5. Usman, K. O., and Memeh, E. Improving students' achievement in further Chemistry using team teaching approach. Review of Education, 2007, 18(1):15-21.

6. Filgona, J. Effects of hands-on learning strategies on students' achievement. 2016, Germany: Lambert Academic Publishers (LAP), 1-165.

7. Akinniyi, F. E., Olalaye, B. O., and Adewumi, A. A. The state of quality teaching/learning in pre-service chemistry teacher education programme. Nigerian Journal of Curriculum Studies, 2008, 15(4), 55-61.

8. Linda, D. Teachers quality and students' performance: A review of state policy in glass (Ed). Electronic Journal on Educational Policy Analysis Archive, 2000. Retrieved from http:www.scholar.google.com.

9. Clark, G., and Wareham, T. Geography at University. 2003, London: SAGE Publication Ltd.

10. Eisner, E. W. Benjamin Bloom (1913-99). Paris, UNESCO: International Bureau of Education, 2000, 3-56.

11. Bloom, B. Learning for mastery. Evaluation Comment, 1968, 1(2), 1-5. 
12. Oluwatosin O. B., and Bello T. O. Comparative effect of mastery learning and mind mapping approaches in improving secondary school students' learning outcomes in physics. Science Journal of Education. 2015, 3(4), 78-84.

13. Anderson, J. R. Learning and memory: An integrated approach (2nd edition.). 2000, New York: John Wiley and Sons, Inc.

14. Abakpa, B. O, and Iji, C. O. Effect of mastery learning approach on senior secondary school students' achievements in geometry. Journal of Science Technology Association, Nigeria, 2011, 46(1):165-176.

15. Akinsola, M. K. Mastery learning, cooperative mastery learning strategies and students' achievement in integrated science. 2007. Retrieved on September 20, 2011 from http/www.ipn.unikiel. deprojket/ esenal lbook/1132.

16. Hussain, I., and Suleman, Q. Effect of Bloom's mastery learning approach on students' academic achievement in English at secondary level. Journal of Literature, Languages and Linguistics, 2016, 23, 35-43.

17. Lamidi B. T., Oyelekan, O. S., and Olorundare, A. S. Effects of mastery learning instructional strategy on senior school students' achievement in the mole concept. Electronic Journal of Science Education, 2015, 19(5): 1-20.

18. Udo, M. F., and Udofia, T. M. Effects of mastery learning strategy on students' achievement in symbols, formulae and equations in chemistry. Journal of Educational Research and Reviews, 2014, 2(3): 28-35.

19. Obiageli, E. F. Influence of concept maps on achievement retention of senior secondary school students in organic chemistry. Journal of Education and Practice, 2013; 4(19):35-43.

20. Filgona, J., Sababa, L. K. Filgona, J., and Ndatuwong, L. G. Effects of concept mapping and brainstorming instructional strategies on junior secondary school students' achievement in social studies in Mubi Educational Zone, Nigeria. British Journal of Education, Society E Behavioural Science, 2016, 18(2): $1-18$.

21. Mitee, T. L., and Obaitan, G. N. Effect of mastery learning on senior secondary school students' cognitive learning outcome in quantitative Chemistry. Journal of Education and Practice, 2015, 6(5): 34-38.

22. Agboghoroma, T. E. Mastery learning approach on secondary students' integrated science achievement. British Journal of Education, 2014, 2(7): 80-88.

23. Adeyemo, S. A., and Babajide, V. F .T. Effects of mastery learning approach on students' achievement in physics. International Journal of Scientific E Engineering Research, 2014, 5(2): 910-920.

24. Singh, Y. K. Teaching of social studies. 2004, New Delhi: APH Publishing Corporation.

25. Rao, D. Science education in developing countries. 2001, New Delhi: Discovery Publishing House.

26. Yore, L. D. What is meant by constructivist science teaching and will the science education community stay the course for meaningful reform? Electronic Journal of Science Education, 2001, 5(4).

27. Zoller, U. Teaching tomorrow's college science courses: Are we getting it right? Journal of College Science Teaching, 2000, 29(6), 409-414.

28. Effandi, Z., and Zanaton, I. Promoting cooperative learning in Science and Mathematics Education: A Malaysian perspective. Eurasia Journal of Mathematics, Science and Technology Education, 2007, 3(1), 35-39.

29. Wambugu, P. W., and Changeiywo, J. M. Effects of mastery learning approach on secondary school students' Physics achievement. Eurasia Journal of Mathematics, Science E Technology Education, 2008, 4(3): 293-302. 
30. Davis, D., and Sorrell, J. Mastery learning in public schools. Educational Psychology Interactive. Valdosta, GA: Valdosta State University. 1995. Retrieved January 3, 2013 from http://teach.valdosta.edu/whuitt/files/mastlear.html

31. Ajogbeje, O. J. Path-analytic model and the effect of some teaching strategies on variables affecting achievement in junior secondary school mathematics in Ondo State. Unpublished Ph.D. Thesis, Ekiti State University, Ado - Ekiti, Nigeria, 2012.

32. Majid, E. D., and Zahra, S. K. Effect of mastery learning method on performance and attitude of weak students in chemistry. 2010, Iran: Elsevier Ltd.

33. Olufunmilayo, I. O. Enhanced mastery learning strategy on achievement and self-concept in senior secondary school chemistry. Humanity and Social Sciences Journal, 2010, 5(1):19-24

34. Patricia, W. W., and Johnson, M. C. Effects of mastery learning approach on secondary school students' Physics achievement. Eurasia Journal of Mathematics, Science \& Technology Education, 2007, 4(3), 293-302.

(C) 2017 by the authors; licensee Preprints, Basel, Switzerland. This article is an open access article distributed under the terms and conditions of the Creative Commons by Attribution (CC-BY) license (http://creativecommons.org/licenses/by/4.0/). 